\title{
Article
}

\section{Do we need cross border education?:} A Case of Pilot Course Multiprofessional Approaches to Substance
Abuse Care and Working with Addicts

by

Tarja Orjasniemi, PhD

Senior lecturer, University of Lapland

Kantokatu 4-6 4, 96100 Rovaniemi, Finland

Tel: +358 407422022

E-mail: Tarja.Orjasniemi@ulapland.fi

Jóna Margrét Ólafsdóttir, $\mathrm{PhD}(\mathrm{c})$

Adjunct lecturer, University of Iceland

Thinkhólsbraut 37, 200 Kópavogur, Iceland

Tel: +3548600665

E-mail: jona@hi.is

Keywords:

cross-border education, multi-professional collaboration, substance abuse, a pilot course, Barents Cross-Border University, thematic network of social work

\section{(c) (7) (?)}

This work is licensed under a Creative Commons Attribution-ShareAlike 4.0 International License. 


\section{Abstract}

The aim of this article is to examine students' experiences of cross-border education based on a single course carried out in collaboration between two networks, Barents Cross-Border University (BCBU) and the Thematic Network of Social Work (TNSWUA), as well as the experiences of teachers in the course. The course was a part of the curriculum for the Master's Degree Programme (BCBU) in Comparative Social Work. Most of the students were studying in this Master's Programme, some of them were exchange students at the University of Lapland (UL) and the rest were social work students at UL and the University of Iceland (UI). The course ran for two weeks in April 2015, and included lectures, discussions and workshops; parts of the course were delivered electronically, while other sections were delivered by teachers on-site.

This course provided a broad multi-professional introduction to the field of addiction and substance abuse care. Students learned about screening the alcohol culture and the relationship between society, addiction, gender, family, life phases, ageing, maternity and substance use. The data for this study was collected through focus group discussion, with students reflecting on one question: 'Do we need cross-border education?' Data from instructors was collected through discussions during the planning and post-course discussions.

Overall, the experiences of students and instructors were positive. The collaboration did not face insuperable challenges. The findings highlighted four main themes: globalization, networking, comparing theory and practice, and using technology. Globalization has set new demands for social work and its professionals. Experts in cultural diversity and international social issues, as well as people with a comparative approach to different societies, are needed the world over. Regarding implications for cross-border education, we would recommend collaboration in the particular field of social work, developing specific courses together supported by both universities and international networks of universities.

Keywords: cross-border education, multi-professional collaboration, substance abuse, a pilot course, Barents Cross-Border University, thematic network of social work 


\section{Introduction}

Cross-border higher education refers to the movement of people, programmes, providers, curricula, projects, research and services in higher education across national jurisdictional borders. Over the last two decades, cross-border higher education through student-, academic staff-, programme- or institutional mobility, and professional mobility has grown considerably (Cross-border Tertiary, 2007).

This article asks whether we need cross-border education courses in light of these developments. This question arose in the first meeting of the authors in 2014 as we started to plan an educational collaboration between two networks, the Barents CrossBorder University (BCBU) and the Thematic Network of Social Work in the UArctic (TNSW).

For this education project, we concluded we would conduct a single university level social work course together. In this case, 'together' meant collaboration between several universities: the University of Iceland (UI), the University of Lapland (UL/Finland), the Northern State Medical University (NSMU/Russia), the Northern (Arctic) Federal University (Narfu/Russia) and the Petrozavodsk State University (PetrSU/Russia). We chose to undertake our collaboration in the course: 'Multiprofessional Approaches to Substance Abuse Care and Working with Addicts'. It is a compulsory course in the Master's Degree Programme (BCBU) in Comparative Social Work. In addition, the course is offered to social work students and exchange students from UL. In total, there were four instructors responsible for the collaboration that represented UI (1), UL (2) and NSMU (1), with the students participating in the online course in Rovaniemi (Finland), Reykjavik (Iceland), Archangelsk (Russia) and Petrozavodsk (Russia). The authors of this article are instructors from UI and UL and taught in the course.

During our planning discussions, we found that there is a huge need to collaborate more closely in the field of social work, especially in the area of addictions and substance abuse. Alcohol abuse is one of the issues that every country has to address, and there has been an increase of substance abuse and related social problems. There is a higher incidence of poverty, unemployment, diseases and domestic violence as a consequence of heavy consumption of alcohol, and it is often these issues that social workers are helping individuals and families to address 
(Goodman, 2013). Despite the differences between countries in alcohol consumption and its consequences, it is clear that social workers everywhere are dealing with issues related to drinking problems in their work with many clients. We shared Lala and Straussner's idea (2012) that social work students often find it difficult to work with addicts and their families, and they need to learn more about this area during their studies.

The decision to conduct the pilot course was made in spring 2014. The planning meetings of the responsible instructors started in December in 2014, and the first introductory online lecture was given from UL in February 2015. After this lecture, the students started to write an essay on a topic chosen by themselves, though under strict supervision. The pilot course was carried out in April 2015 for two weeks. There were lectures given by four instructors (4-8 hours/teacher), each of which concentrated on different areas of substance abuse and working with addicts from a comparative perspective, as well as three workshop days for presentations by students.

\section{The Master's Degree Programme: BCBU and UArctic}

The Master's Degree Programme in Comparative Social Work (CSW) is an international two-year programme (120 ECTS), which has been developed within the frameworks of Barents Cross-Border University (BCBU). BCBU offers and creates a setting for a cross-border learning environment between the universities in Northern Finland and North-West Russia, and also in the entire Barents region. The programme structure includes: 1) joint studies arranged within a collaboration between universities (80 ECTS), and 2) studies offered by home universities (40 ECTS). The main partners carrying out the joint studies in the programme are the University of Lapland, the Northern (Arctic) Federal University, the Murmansk State Humanities University and the Petrozavodsk State University, with the. Northern State Medical University (Archangel, Russia) participating as an associate partner. Most of the joint studies are online courses arranged within the framework of the BCBU IT Campus. The CSW Programme was awarded the University of the Arctic Master's Endorsement Label for four academic years, which extended through to the end of the 2015-2016 academic year. 
During the CSW programme, students acquire a better understanding of national and global social work through a comparative approach. Graduates from the programme can work as social workers in multicultural environments, as well as experts in international projects and tasks in the social sphere. The mobility of students between Finland and Russia is an essential part of the programme. For example, during the summer and winter school sessions, student visits and practice training in the neighbouring country provide opportunities for students to familiarize themselves with social work in different contexts and societies.

In addition, the University of Lapland is a partner organization of the thematic network of social work (TNSWUA). TNSW is a part of the UArctic network, thereby contributing to the development of social work education in universities and colleges in the Far North. The network is involved in research and teaching, with one aim of this field of teaching to discuss content and curriculum in social work education to help inspire the schools to implement findings and knowledge of social work in our part of the world; course development was one of the most important activities in 2015 (The University of Arctic (UArctic), 2015). We can therefore say that the aims of the two university networks in the field of social work education are identical.

The specific social work course we developed together, the Multi-professional Approaches to Substance Abuse Care and Working with Addicts course, is conducted by the University of Iceland and the University of Lapland together with the Northern State Medical University. It is the initial effort in running a single course in collaboration with BCBU and TNSWUA.

\section{The Course: Multi-professional Approaches to Substance Abuse Care and}

\section{Working with Addicts}

Multi-professional Approaches to Substance Abuse Care and Working with Addicts is a compulsory course of joint studies of the CSW programme (University of Lapland, 2013). The course covers social, cultural, psychological and medical factors of substance use and risk of addiction. First, students learn about screening the alcohol culture and the relation between society, gender, family, life phases, ageing, maternity and substance use. Second, they learn the different theoretical and multidisciplinary approaches to addiction, the risk factors of different kinds of addiction and the analysis 
of those differences, as well as the main symptoms of addiction. Finally, students learn about primary and secondary prevention of alcohol and drug abuse, multi-professional approaches in a field of substance abuse care and about scientific research work in alcohol and drug abuse.

This course focuses on international aspects of social problems, specifically alcohol problems, and social work with substance abusers. Though the issues each country or community faces may be unique, the research-driven knowledge, experiencebased insight and field-tested skills required to address them are endlessly adaptable. According to Lala and Straussner (2012, p. 127), social work students often find it difficult to work with addicts and their families who may be perceived as a threat. In recent years, it has been necessary to increase students' knowledge in this area. In addition, students' interest in this area has increased, perhaps because of increased alcohol consumption and related social problems.

\section{Statistics on alcohol consumption in Finland, Iceland and Russia}

Alcohol is one of the issues that every country has to address, although the problems arising from excessive drinking can be weighted differently in different countries. For example, it is highly likely that poverty, unemployment, diseases and domestic violence are consequences of excessive consumption, and that these are often issues that social workers address with individuals and families (Goodman, 2013, pp. 112, 116).

In 2012, the European Union (EU) region had the highest annual alcohol consumption in the world. According to alcohol sales data, the average annual consumption was over 10 litres of pure alcohol per adult in EU states in 2012. Eastern European countries reported on alcohol consumption, with 12 litres or more per adult per year on average, but according to the World Health Organization (WHO), Russia reported over 15 litres per adult. In comparison, the Nordic countries like Iceland and Norway reported from six to eight litres of pure alcohol per adult. Alcohol use has been increasing in some Nordic countries, e.g., in Finland and Sweden, although these countries are still below the EU average. The EU concern is that alcohol-related damage is the principal reason for a lack of public health, both in terms of morbidity and mortality. Furthermore, according to the EU, alcohol it also contributes to death, 
accidents and injuries, violence, homicide and suicide, particularly among young people (OECD/European Union, 2014).

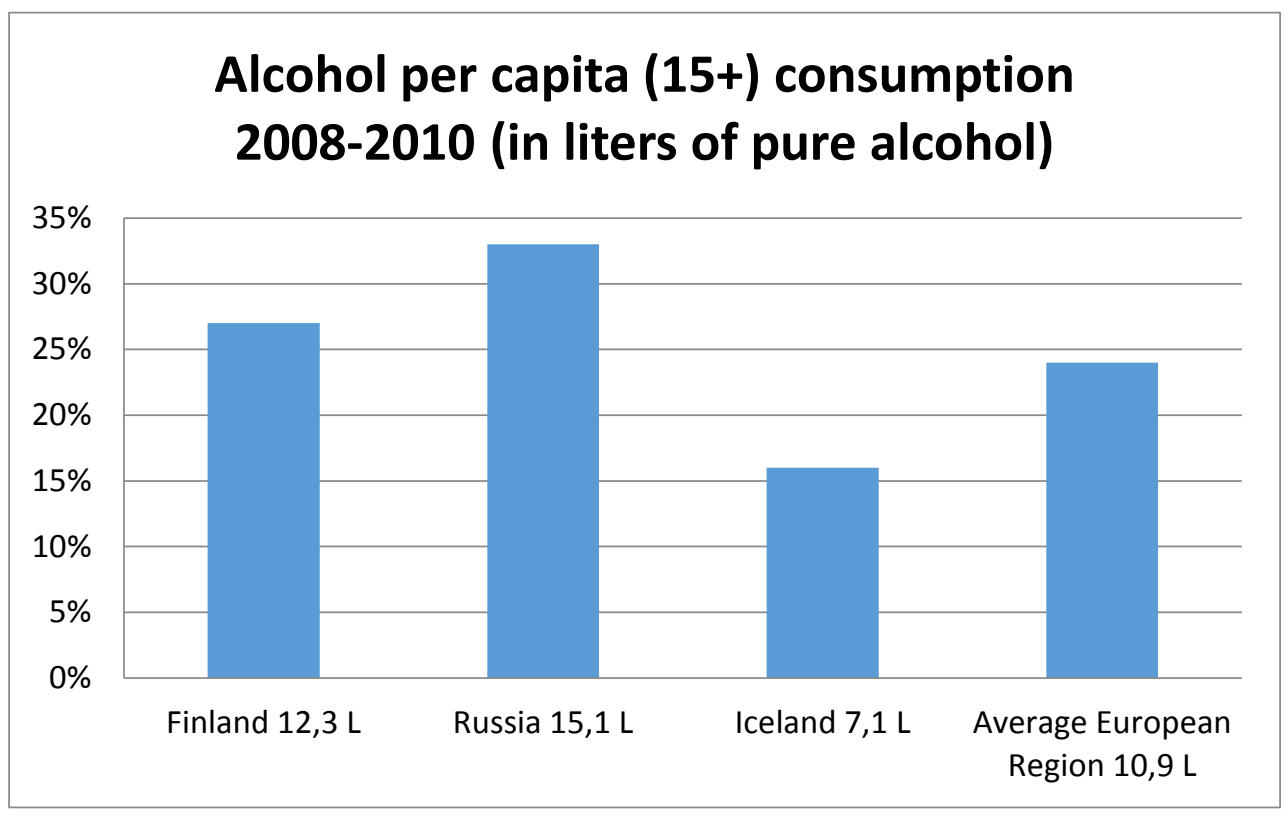

Chart 1: Chart Alcohol per capita (15+) consumption 2008-2010 (in litres of pure alcohol per year)

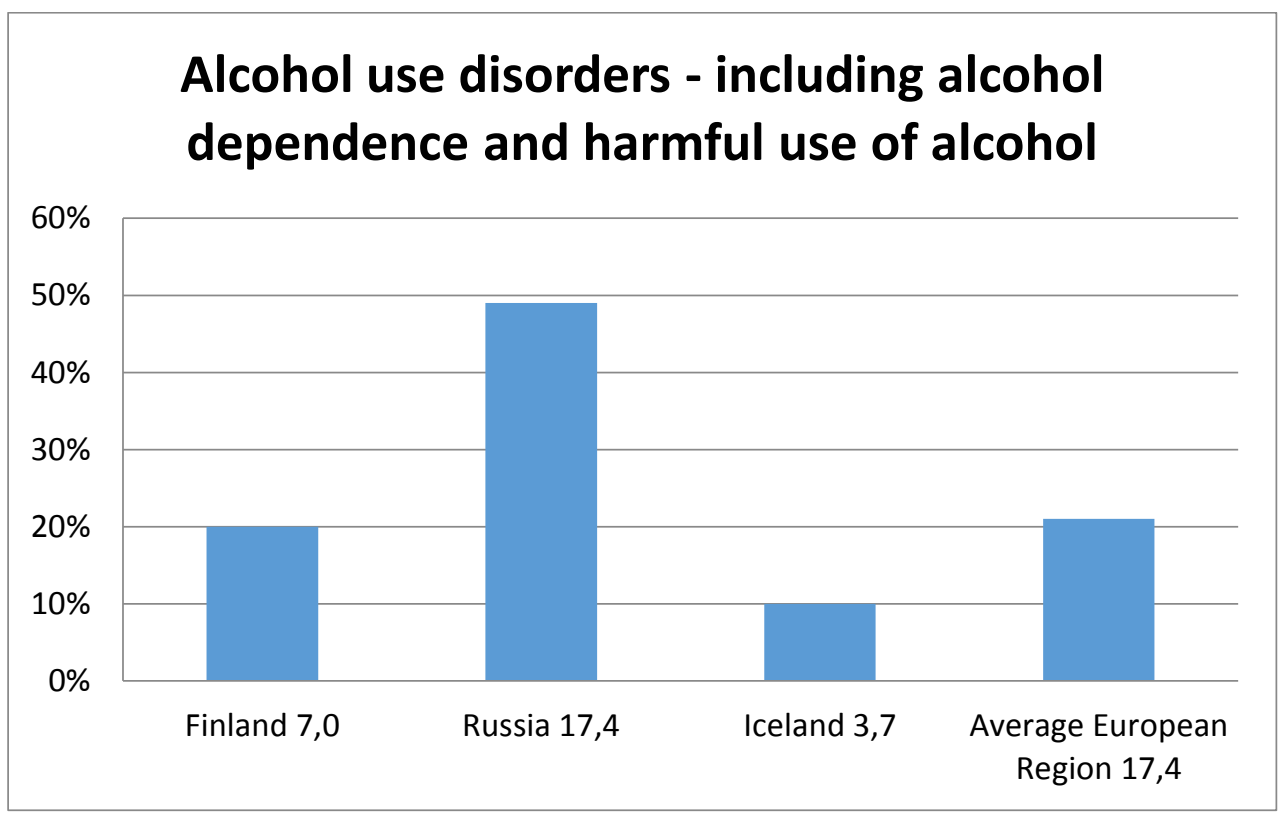

Chart 2: Alcohol use disorders - including alcohol dependence and harmful use of alcohol (WHO e.n. a, b, c)

In Finland, the use of alcohol has increased considerably over the last four decades. Apart from the economic recession in the early 1990s, alcohol consumption and the related harm increased in Finland until the end of the first decade of the 2000s. Since 
2009, the consumption of alcohol has declined, and the detrimental effects of alcohol seem to be declining as well. According to the Finnish National Institute for Health and Welfare, Finns still drink more alcohol per capita than any of the other Nordic nationalities (Terveyden ja hyvinvoinnin laitos, 2015).

In 2010, Russia ranked fourth in terms of alcohol consumption per capita, which was 15.1 litres/year. This excessive consumption demanded that the government take not only the medical and social, but also the economic and political measures needed to reduce alcohol consumption. At the beginning of the 2010s, Russia launched a campaign to reduce alcohol dependency among the population (Orjasniemi \& Soloviev, 2014.)

Despite the fact that there are differences in the amount of alcohol consumption and harmful drinking, changes in abstinence and alcohol usage across generations and between sexes are common, and show how these changes have taken place globally. Alcohol culture acts like a mirror; it reveals what's going on in society (Orjasniemi, 2005). Despite differences in the prevalence of harmful drinking, social work is facing huge challenges connected to alcohol abuse in every country.

\section{The Problem: Alcohol abuse, addiction and social work}

During recent decades, there has not been a unified approach to the concepts of alcohol abuse and methods of treatment in most communities. This may be because there has been such a complex range of trends in the theories of addiction, public policy on the issue and professionals' treatment methods (Keen, 2010, p. 4). In the past 100 years, the understanding of alcohol use has increased, not only from the perspective of the individual consuming alcohol excessively, but also in the context of how consumption affects his/her environment and their families. Consumption not only affects the mental and physical health of the individual, but also his/her social and economic environment (Meyers, Apodaca, Flicker, \& Slesnick, 2002, pp. 285-6).

Alcohol and drug use has always been controversial, and can often be a political issue. There have been conflicts between alcohol and drug users themselves, researchers, professionals who provide treatments and politicians (Doweiko, 2012, pp. 7-8). Three main theories of addiction have been applied in analysis: 1) social theories, 2) biological-genetic disease theory, and 3) nerve and brain disease theory. All of these 
theories are used today to work with alcohol addicts, and to create alcohol and drug policies in the field (Keen, 2010, p. 5). Other theoretical approaches and practices have been developed in recent years, which include psychological therapy, cognitive behavioural therapy, motivational interviews and a solution-based approach (Doweiko, 2012, pp. 408-409; Miller \& Rollnick, 2001, pp. 26-27). Analysis models have been developed from the latest theories and knowledge that have defined alcoholism as a disease. Analysis models are based on the diversity of individuals with alcoholism, so the disease is diagnosed in the best possible way (American Psychiatric Association [APA], 2013, pp. 483-485).

Today, scientists are still defining addiction. Using the International classification of diseases (ICD 10), the World Health Organization defines addiction as an uncontrollable desire for alcohol or other drugs. For example, the individual has no control over his alcohol or drug use, and consumption becomes an even higher priority than before. There is a collection of cognitive, behavioural and physiological factors that may contribute to an addiction to alcohol, drugs, prescription drugs or tobacco (WHO, n.d.; APA, 2013, p. 485).

According to the American Psychiatric Association in the Diagnostic Statistical Manual of Mental Disorders (DSM 5), a serious addiction and alcohol or drug abuse are defined by the following: consumption patterns that adversely affect the social, physical and psychosocial factors. Daily functioning is hence maintained despite the negative effect on the individual (APA, 2013, pp. 283-485).

Within psychiatry, addiction is regarded as a long persistent disease characterized by three factors: 1) compulsive use and consumption of alcohol and/or drugs, 2) violent objection to limit the amount of alcohol and/or drugs, and 3) consumption governed by negative emotions, such as distress, anxiety and frustration when the alcohol and/or drugs are not available (Kobb \& Volkow, 2010, p. 1).

In daily life, stress can affect the brain's chemistry, and people can self-medicate by using alcohol to relax. Research on both animals and humans shows that stress can also be a significant factor in whether a person becomes addicted to alcohol or other drugs (Anzaldua et al., 2011, p. 158; Johnson \& Stone, 2009, pp. 5-6). Thus, an 
individual's reason for consuming a substance may be to relax and get away from stress factors in the environment at work and in their personal life (Ólafsdóttir \& Hrafnsdóttir, 2011, p. 46; Colder, Chassin, Lee, \& Villalta, 2010, pp. 111-112).

The emphasis in social work is to work with interactions between people and subsystems, such as the family and other systems in the social environment (Thompson, 2005, p. 13). With increasing demands in the modern world, people's lives are getting more complicated, and there are more social problems that need to be resolved (Farley, Smith, \& Boyle, 2010, pp. 15-16). Despite the differences between countries in alcohol consumption and its consequences, it is clear that social workers everywhere are dealing with issues related to drinking problems in their work with many clients.

Social workers are currently practicing in a complex world. They need to understand the forces of globalization from an economic, ecological and social perspective to help connect with their international colleagues, and to represent them in an informed fashion at an international level. This applies whether they are delivering social services directly or in hospitals, or whether they are participating in international or internal policymaking. A broader awareness of such demands on the social work profession in the 21st century is needed (Hare, 2015, p. 408; Lyons, 2006, p. 368). It is therefore necessary for the social sector to be aware of the evidence-based methods being used in treatment and counselling for addicts and their families in other countries, in addition to the policies followed in the field. A study based and built upon a global perspective on alcohol and drug problems can benefit everyone who is working with addicts and their families in one way or another. This international knowledge about alcohol use and misuse is important in our contemporary world without borders (Lyons, 2006, pp. 369-370).

Social workers are driven by social justice and social change. They are not only interested in the individuals' or families' changes, they are also interested in social changes that benefit individuals and families. As professionals, social workers should also have an interest in changes in policies and in the communities that contribute to the prevention of discrimination of minority groups (Nelson, 2012, p. 20; Thompson, 2005 , p. 105). Social workers deal with addicts in many contexts, and it is common in 
the work to deal with issues of the clients' relatives, such as parents, spouses or siblings (Lala \& Straussner, 2012, pp. 128-129).

Research reveals that children in families where there is substance abuse live in a very stressful environment (Velleman, Templeton, Reuber, Klein, \& Moesgen, 2008). Substance abuse among pregnant women is a big risk factor for children who grow up with parental addiction and witness how their parents cope with life (Hunting \& Browne, 2012). The UN reports that roughly 4.5-7.7 million children under the age of 15 live in a household where parents abuse alcohol, and over 100 million children live in households where there is substance abuse and domestic violence (Velleman et al., 2008 , p. 391). According to the UN, $25 \%$ of women will be victims of domestic abuse in conjunction with substance abuse at some point in their lives, and that women with children are twice as likely to be victims of domestic abuse than single women (without children) (Pinheiro, 2006; Walby \& Allen, 2004). Data from the World Health Organization (WHO) indicates that $5.4 \%$ of all illnesses and household accidents are connected to alcohol and substance abuse (WHO, n.d. a). The discourse on alcohol and substance abuse often focuses only on the individual who is addicted. Yet, there has been some discussion of how the individual's misuse can affect other family members to the point that they live in very detrimental circumstances (Vernig, 2011).

\section{Data collection and analysis}

The aim of this article is to examine both students' and teachers' experiences of crossborder education based on a course, Multi-professional Approaches to Substance Abuse Care and Working with Addicts, which was carried out in collaboration between two academic networks, as well as the experiences of reliable teachers. The main emphasis is on students' experiences.

We used a focus group discussion (FGD) to collect data from students. A FGD is a good way to gather together people with similar experiences to discuss a specific topic of interest. A focus group is a small group of six to 10 people led through an open discussion by a skilled moderator. The group needs to be large enough to generate a rich discussion, but not so large that some participants are left out (Mäntyranta \& Kaila, 2008). The moderator introduces topics for discussion, and helps the group to participate in a vigorous and natural discussion among themselves. There were nine 
students participating in the focus group discussion, and after the intensive course they knew each other well, so it became a lively discussion.

\begin{tabular}{|l|l|}
\hline \multicolumn{2}{|l|}{ Multi-professional Approaches to Substance Abuse Care and Working with Addicts } \\
\hline Students & Country \\
\hline CSW students & $\begin{array}{l}\text { Finland, Nepal, Bangladesh, Swasiland, } \\
\text { Kenya, Russia }\end{array}$ \\
\hline $\begin{array}{l}\text { Social work Programme, University of } \\
\text { Iceland }\end{array}$ & Iceland \\
\hline $\begin{array}{l}\text { Social work Programme, University of } \\
\text { Lapland }\end{array}$ & Finland \\
\hline Exchange students & Austria, Spain, China \\
\hline
\end{tabular}

Chart 3: Students participating in the course according to student status and home country

The discussion was held at the end of the course, and some of the students participated in it online. Not all the students attending the course were able to stay for the discussion because of a lack of time. First, the instructors presented the topic, 'Do we need cross-border education?' to the students, and after ensuring that the idea was clear, left the room and let the students discuss the topic among themselves. The chairperson and secretary of the group were appointed by the instructors, and the secretary recorded the minutes.

Meanwhile, the instructors from UI and UL had their own discussion on the same topic, and summarized their experiences of the collaboration during the entire process. The first planning meeting of reliable instructors of the course was held in December 2014, and there were instructors from Arkangel/Northern State Medical University (1), Rovaniemi/University of Lapland (2) and Reykjavik/University of Iceland (1). We had online meetings once a month, and we also shared our ideas by email. UL coordinated the practical issues.

\section{Results}

When analysing the data using a content analysis from students, we found four main themes: globalization, networking, comparing theory and practices, and using technology. The following quotations demonstrate experiences that social work students had through this course as a part of cross-border education. At the end of the results, there is a short summary of the teachers' views of cross-border education. 


\section{Globalization}

Globalization has given the world opportunities to bring people together in ways previously undreamt of in both the real and virtual worlds. Globalization is a contested term, and there is no agreement over the definition. Globalization has had a significant impact on social work practice, and has affected the profession in several ways. Most of the impacts have been very challenging to social work (Dominelli, 2010). For example, according to Dominelli (2004b), globalization increases the movement of social workers who train in one country and go to work in another.

Both teachers and students shared the idea that globalization has transformed the way we live, work and learn, and that education must prepare young people to flourish in this new and changing world. The students said that language studies were important for social workers in this globalizing process:

Social work students should have more courses in English, even in the basic programme, because the world is getting more global and clients are becoming more international.

The younger generation has become aware that global issues are highly relevant to their future lives, and therefore understand the purpose of their learning in an international context. As the students said:

Cross-border education is really important, as the world has become very global. And additionally, a good cross-border experience is to literally cross the border, it's more eye opening.

Based on the above, cross-border education will develop the kind of knowledge, skills and attributes that will equip future social workers professionally, socially and personally to thrive in the 21st century (see Vincent-Lancrin, 2007). Social workers must develop an awareness of global issues and events, as well as the skills and confidence to be professional social workers in an increasingly global society. According to the students, it is 'important to know how social work is done around the world'.

The priorities of social work practice vary from country to country and over time, depending on cultural, historical, legal and socio-economic conditions. Students are aware of this diversity in social work, and they see that, 'for example developing countries can learn many things from developed countries'. 
Social work is an international profession. According to the international definition of social work (The Code of Ethics 2012): 'The social work profession promotes social change, problem solving in human relationships and the empowerment and liberation of people to enhance well-being.' Utilizing theories of human behaviour and social systems, social work intervenes at the points where people interact with their environments. Principles of human rights and social justice are fundamental to social work.' Learning in a cross-border context of social work education offers a good opportunity to deepen a student's knowledge about the social work profession.

Furthermore, one of the ethical practice principles instructs social workers to respect people's beliefs, values, culture, goals, needs, preferences, relationships and affiliations. Social workers should recognize their own prejudices to ensure they do not discriminate against any person or group, as they should ensure that services are offered and delivered in a culturally appropriate manner (The Code of Ethics, 2012). Social work with immigrants and refugees is growing and is an important field all over the world, with social workers playing a crucial role in work with immigration issues. In this field, there is a need for social workers who have experience with a culturally sensitive, multicultural social work practice (see Derald Wing, 2005). Students are aware of the challenges of immigration to social work practice - both linguistically and culturally:

There are nowadays people from different countries in our countries, for example it's easier to understand foreign customers and their cultures, ways of acting, etc. in your home country because of this cross-border experience and to work with them more effectively.

It is good to have opinions from all around the world on this issue because you will know in the future if you have a client from these countries, how to treat them, or what their 'culture' is in relation to drugs, and you can start to treat them better than if you don't know anything about them.

In students' opinions, this approach to education and course work is positive, as it may open opportunities for them in their work lives.

Cross-border education broadens our thinking, we can understand problems from a global perspective, and be better equipped to work in multicultural organizations like the UN. 
Students were very familiar with the globalization issues (see Vincent-Lancrin, 2007). They saw that learning in a cross-border context offers skills and knowledge to manage the effects of globalization in their future work. They were also aware of how their future work is increasingly shaped by globalization.

\section{Networking}

A social network is defined as a set of socially linked or interconnected discrete individuals or groups, in addition to the structure, number and character of the relationships that link members of the network (Hawkins and Maurer, 2012, p. 355). In this paper, we argue that networking is like building and maintaining contacts. Nowadays, social workers are increasingly interested in networking with each other to share their knowledge. In fact, social workers should be highly skilled at networking, because building relationships is at the core of their work.

Networking can help students to develop relationships and build a community of support and influence for their professional life. Attending cross-border education (courses or programmes) is an excellent way to network while continuing to build professional skills and learning about cutting-edge practices in the social work field. According to the students:

It is very educational and exciting to get to know people from different countries.

Attending cross-border education offers an opportunity to network with other emerging professionals. To connect with people from other institutions during studies can be an incentive to participate in future conferences of colleagues' organizations, seminars or continuing education in one's own area of interest. Networking with other future social workers is about nurturing relationships over time, gathering information and expanding knowledge about what is occurring in the social work field. The demand to keep up to date with relevant research and learning from other professionals is one of the principles of ethical practice (see The Code of Ethics, 2012).

Students are familiar with using social media in networking with others. CSW has its own Facebook group, with CSW students, teachers, practical teachers (supervising social workers), visiting teachers, exchange students and so on joining the group in recent years. It has been a very useful tool for sharing information and focusing on the 
Master's Programme. This same thing occurred during this course. As the students said:

It's important to connect people from other institutions for future social work.

Networking in a cross-border context helps build relationships with future colleagues from abroad, as students were aware of the academic and professional networking opportunities in this context.

\section{Comparing theory and practice}

The students of the course had different backgrounds and were from different continents, such as North and South Europe, Asia and Africa. Alcohol consumption is a growing problem which every country needs to address. Each country has a different alcohol culture and drinking habits, but when alcohol consumption is a problem it leads to the same health problems with social consequences in every country, as Sunday et al. (2011), Johnson and Stone (2009), Fallon et al. (2011) and Nikulina et al. (2011) argued in their research. According the students, this is a good thing:

to get to know different systems and policies in different countries, and it's important to know about comparative approaches.

Students in the cross-border course had to write an essay based on their own interest in the field of alcohol use, alcohol abuse and substance abuse care. Most of the essays include the comparative approach, as did discussions during the lectures. It is very fruitful when students from different cultures and countries are comparing their alcohol cultures, social and alcohol policies and social and health services. They were very interested in hearing about different practices and methods of working with addicts, especially working with families, youth and the elderly. In the focus group, students said:

It's nice and beneficial that the teachers come from different countries.

However, it is not only lectures given by instructors, but the presentations by students themselves, which expand their knowledge about alcohol issues in different countries. For some students it was the first time they had written an essay in English, which was good practice. According the students, learning and practicing foreign languages are very important for social workers in the globalization process. Some exchange 
students were just following the lectures and students' presentations without writing any essay since it was not a compulsory course for them.

\section{The Themes of Students' Essays}

The role of the family and surroundings in rehabilitation of addicts and self-help group therapy

Addiction (Spain)

Substance abuse prevention among youth in Finland

Substance abuse - Perspective of siblings and parents (Iceland)

A review of Finnish adolescents' alcohol use and resultant problems

Dependence and main symptoms of addiction

Prevention work of substance abuse in Russia

Drug use in Nepal and the role of families and surroundings in interventions for addicts

The relationship between gender, life phases, ageing and substance use

The social and psychological peculiarities of addictive persons

Alcohol use and social media

Chart 4: Themes of students' essays

According to the students, the class discussions during the lessons are also fruitful. Chinese students' attendance in the course was very productive for the entire group, because Chinese alcohol culture is still fairly unknown abroad. They learned from each other and saw this as important, noting: use cross cultural learning academic aspect plus practical issues discussed, so you can experience and discuss how things are done. Instructors represented Finland, Iceland and Russia, but students came from around the world. For example, comparisons between east and west, north and south, and between religions and developed and developing countries, were interesting to hear. Students commented that this heightened their learning and analysis:

When doing an internship in another country my eyes were opened more to see how the system really works in that country for better and for worse, and how maybe the culture affects the system, etc.

Interesting to hear foreign teachers talk about substance abuse, and the discussions between the lectures from different countries are fruitful 
Students liked to hear and discuss practical issues, and not only theoretical ones. As an example of good practice in substance abuse care, students were presented with An Empowering Tree Model (Sipola, 2014). This model was developed by social workers in A-clinic of Kemi, an open care clinic for substance abusers in a city located in the north of Finland, which is a very practical tool for working with a group of alcohol abusers. For instance, the students said that it is useful to hear different kinds of good practices from different countries, and different ideas and different views, and bring them to our own work. According to a non-European student:

Internship in another country was really interesting because, for example, when coming from developing country it can be really different, a different policy, and I learned many things about how to work in Nordic countries and can take what I learned back home.

Students' feedback on the course was positive. They liked the comparative approach in both lectures and presentations and the inclusion of different areas of substance abuse and working with addicts. The course was a good learning experience for the students.

\section{Use of technology}

Cross-border education is always based on Virtual Collaboration, so the use of technology is very important in course delivery. The partner institutions have to be linked together with common web conferencing and learning management systems to begin with, and then, to enhance cooperation virtually over the Internet. This kind of Virtual Campus has been developed by the Kolarctic ENPI CBC BCBU+ project to partner universities. One of the key goals of the BCBU+ project was to give educational institutions opportunities to strengthen cross-border relations and strengthen the existing network by establishing a common E-Learning and Web Conferencing platform, and developing the Virtual Campus (Collin et al., 2013.) According to students, it is good to learn to use IT during the studies. One student noted that:

During my internship I learned how to take advantage of technology, for example, using Skype when helping people in different parts of Lapland - you can call and ask for help even though you live far away.

They can use these skills in their future work. Adobe Connect is the main tool for holding E-Learning classes at the University of Lapland in 2015. Adobe Connect is a Web Conferencing platform used for meetings, E-Learning and webinars. There is no 
need to install anything on your own computer so the access is very easy, and all of the functionalities are extremely easy to find and use. When everything works properly, the participants are watching the document simultaneously, some are chatting, almost everyone is seeing each other with live streaming video, and it simply creates a very interactive and collaborative meeting environment. The lectures can also be recorded so that the students can listen to them later on (see Collin et al., 2013). But according to the students there were some problems, which were: limitations in communication and using technology. Not all students had equal access to the appropriate technology or setting. Because Russian students were following the online lectures at home and not in a classroom with a sufficient infrastructure built by the BCBU+ project, there were some problems with the Internet connection. Students noticed this and commented that: Not everyone has a mic and when we are connecting with people in other countries, the communication is different, it's not the same.

As pointed out by students, there is no technical support designed for a remote desktop: so it's very frustrating if the technology doesn't work [as], for example, sometimes some people don't hear everything through the online connection. The first step in the BCBU+ project was to equip each Russian partner university with one room with a sufficient infrastructure for multipoint online meetings, web conferences and teaching activities, but in practice it seemed problematic to get the instructors and students to use them in each university. Now, most of the universities have started a regular use of Virtual rooms.

The BCBU+ handbook: A Guide to Establish a Virtual Cross-Border Campus for BCBU Network is useful for implementing a Web-Conferencing system and other related Cross-order Virtual Collaborations for all those interested in long-distance learning. The handbook is targeted at teachers, administrative and IT support personnel in educational institutions, and also for all other interested groups.

The online course always depends on IT and technical support. The active engagement in an online course means that students must have sufficient facilities needed for full participation; based on the students' feedback there is a need for some improvement in this area. 


\section{Teachers' views on cross-border education}

As social work educators, we are aware of the challenges of globalization to social work education, research and practice (see Dominelli 2004, 2010), and we know that there are no complete answers as to how to response to these challenges. One attempt to face the challenges is to collaborate more closely on the field of social work education on the global level. This single course on cross-border context is one example of how to develop new methods in teaching social work. It was carried out from a comparative perspective by an international and multi-professional group of teachers, each representing their own research area (alcohol use, substance abuse, addiction) and international students. As teachers, we shared our knowledge with one another, and gained a lot of new knowledge by hearing the students' presentations.

We reflected on the issue from several points of view, and we summarized our discussion in the following way:

We try to understand globalization and its consequences not only to human life, but to our scientific and professional field; as teachers, we have a responsibility for the professional development and capacity building of students.

We are aware of the gap between generations: future social workers will be working in a different kind of world than the previous generation. Old, traditional explanations are not working any more in a postmodern world.

Social problems do not recognize borders, especially in alcohol and drug use issues; we need collaboration not only on policy or strategy levels, but in education, research and practice.

All partners agreed that cross-border education helps capacity building, professional training, broadening one's outlook and acceptance of multiculturalism, ethnic or linguistic diversities. These themes were very similar to those expressed by the students. Cross-border higher education should be seen as a contribution towards human, social, cultural, scientific and economic development. As the four instructors pointed out:

We have to learn from each other, get to know the best practices, undertake research together and share the understanding of what's going on in our own professional field and in the wider world.

We need a dialogue between different countries, cultures and disciplines. The collaboration in the academic field is much more important in the current political situation in Europe and the whole world.

Globalization was one of the main reasons to conduct this course as a collaboration of two academic networks. Every instructor responsible was willing to develop the 
course despite the fact that it meant more extra work without any extra compensation, as all involved shared the same ideas concerning the globalization. An international course like this is very relevant to the creation of networking between colleagues, and is necessary to provide at the Master's level in Social Work.

\section{Conclusion}

The course, Multi-professional Approaches to Substance Abuse Care and Working with Addicts, focused on alcohol and drug problems and theory and practice, both with the addicts and their families. It also focused on the societal and cultural perspective. The course was a part of the curriculum for the Master's Programme in Comparative Social Work, and was compulsory for CSW students. Most of the students were studying in the international Master's Programme (CSW), some of them were exchange students at UL, while the rest of them were social work students at UL and UI. The course ran for two weeks in April 2015, and included lectures, discussions and workshops; parts of the course were delivered electronically, whereas other sections were delivered by teachers on-site. The pilot course was carried out very successfully, and the feedback from students and teachers was very positive.

There are always some challenges in organizing a course with international collaboration. In our case, it was helpful that every instructor was committed to plan and participate on the course, but naturally the workload was not the same for everyone. The primary responsibility was shared by the authors of this article. Collaboration made visible the different cultures and practices in separate countries and universities. Offering it to students as an elective course at the University of Iceland meant some extra work for the instructor responsible: on content, evaluation, credits and timing. We learned that there is a lot of bureaucracy in organizing something outside of the traditional curriculum.

One of the practical obstacles was the time zone differences between countries. The other practical issue concerned the use of technology, while conducting an intensive course partly online needs sufficient infrastructure and support from IT personnel. The structure of the course was workable, lectures were given by separate teachers and there was time for discussions and workshops. The course was carried out over two weeks, so students had time to get to know each other, and despite their student 
status, students' views on cross-border education were clear. According to the students, there are a lot of benefits in cross-border education, i.e. addressing the impact globalization, the advantages of networking and developing cross-border relationships with others, comparing and sharing theory and practice in each student's environment and learning to use technology that might be applied in future communication with clients.

The main conclusion is that students believe it is important to take part in an international master class in cross-border education. The students' discussions after the course indicated that they believe that students today understand globalization better. Thanks to the Internet and other changes in recent decades, the borders between countries are not as visible as before. Trends and developments in different areas of the field of alcohol problems are not privileged in each country, though these trends are changing, thereby leading to developing and setting policy at an international level. The students felt it necessary to be aware and well informed about this field, so courses like this are valuable in terms of theory and practice, as pointed out by Vernig (2011), Fallon et al. (2011) and Velleman et al. (2008). These results support what Hare (2015) and Lyons (2006) observed, namely that social workers are currently practicing in a complex world. They need to understand the forces of globalization from economic, ecological and social perspectives to help connect with their international colleagues, and to present themselves in an informed fashion at an international level. This international knowledge about alcohol use and misuse is important in a world without borders today; as Dominelli (2005) noted, globalization has internationalized social problems, with their tentacles spreading into many countries, giving nation-states more problems in common. Internationalization has changed the local and incorporated it into the global.

There is a need to develop education from a multicultural, multi-professional, multiscientific and global standpoint. To this end, we recommend that there be more shortterm collaborative education partnerships. Sharing expertise across borders under an umbrella network could be the way forward in this development work. However, this kind of effort cannot depend solely on the vision of individual teachers, it needs to be fully supported by universities and networks across regions and borders. The support from universities has to be not only technical, but also linguistic and financial. The 
professional development work has to be included in the teachers' workload. In addition, international collaboration has to be one of the interests of universities.

In our case, it was substance abuse and social work. Problems of alcohol use and addiction are the same in every country, so we can learn a lot from each other to account with these issues. Sharing the best practices during studies with students helps them deal with alcohol problems, in addition to working with addicts and their families. 


\section{References}

American Psychiatric Association (2013). Diagnostic and statistical manual of mental disorders (DSM-5). Washington, DC: American Psychiatric Association.

Anzaldua, A., Martinez, A., \& Martinez, L. R. (2011). The complex interplay of genetics, epigenetics, and environment in the predisposition to alcohol dependence. Salud Mental, 34(2), 157-166.

Asha, G. (2007). Cross-border Higher Education: India's Response. A Regional Conference on "Strategic Choices for Higher Education Reform" organized by the Ministry of Higher Education Malaysia and the World Bank.

Colder, C. R., Chassin, L., Lee, M. R., \& Villalta, I. K. (2010). Developmental perspectives: Affect and adolescent substance use. In J. D. Kassel (Ed.), Substance abuse and emotion (pp. 109-135). Washington DC: American Psychological Association.

Collin, K., Furberg, L., Edzen, S., Hartikainen, H., Khaymin, E., Mohammed D. M., Pankkonen, K. (2013). BCBU+ Handbook: A Guide to Establishing Virtual Cross-Border Campus for BCBU Network. Kolarctic ENPI CBC Barents Cross-Border University Development Project 2011-2013 (BCBU+), Rovaniemi. Retrieved from http://lauda.ulapland.fi/bitstream/handle/10024/61820/BCBU_HANDBOOKpd fA.pdf? sequence=4.

Derald Wing, S. (2005). Multicultural Social Work Practice. Wiley.

Dominelli, L. (2004b). Social Work: Theory and Practice for a Changing Profession. Cambridge: Polity Press.

Dominelli, L. (2010). Globalization, contemporary challenges and social work practice. International Social Work, 53(5), 599-612.

Doweiko, H. E. (2012). Concepts of Chemical Dependency (8th edition). USA: Thomson Brooks/Cole.

Fallon, B., Trocme, N., MacLaurin, B., Sinha, V., \& Black, T. (2011). Untangling risk of maltreatment from events of maltreatment: An analysis of the 2008 Canadian Incidence Study of Reported Child Abuse and Neglect (CIS-2008). Journal of Mental Health and Addiction, 9, 460-479.

Farley, O. W., Smith, L. L., \& Boyle, S. W. (2009). Introduction to Social Work. Boston: Pearson Education, Inc. 
Goodman, A. (2013). Social Work with Drug, Alcohol and Substance Misusers. Third Edition. London: SAGE.

Hare, I. (2015). Defining social work for the 21st century. The International Federation of Social Workers' revised definition of social work. International Social Work, 47(3), pp. 407-424. London: Sage Publications.

Hawkins, R. L., \& Maurer, K. (2012). Unravelling Social Capital: Disentangling a Concept for Social Work. British Journal of Social Work (2012) 42, 353-370. Retrieved from https://wagner.nyu.edu/files/faculty/publications/Br_J_Soc_Work-2012Hawkins-353-70.pdf.

Hunting, G., \& Browne, J. A. (2012). Decolonizing policy discourse: Reframing the 'problem' of fetal alcohol spectrum disorder. Online (17 April 2016). Retrieved from

http://ehis.ebscohost.com.ezproxy.webfeat.lib.ed.ac.uk/eds/pdfviewer/pdfvie wer? vid $=9 \& h i d=121 \&$ sid $=66092 e 6 a-57 e 3-44 b 2-b 95 c-$

62ee3d4805e1\%40sessionmgr4.

Johnson, P., \& Stone, R. (2009). Parental Alcoholism and Family Functioning: Effects on Differentiation Levels of Young Adults. Alcoholism Treatment Quarterly, 27(1), 3-18.

Keen, J. (2010). Understanding Drug Misuse: Models of Care and Control. New York: Palgrave Macmillan.

Koob, G. F., \& Volkow, N. D. (2010). Neurocircuitry of addiction. Neuropsychopharmacology, 35(4), 217-238. http://www.ncbi.nlm.nih.gov/pmc/articles/PMC2805560/.

Lala, S., \& Straussner, A. (2012). Clinical treatment of substance abusers: Past, present and future. Clinical Social Work Journal, 40, 127-133.

Lander, L., Howsare, J., \& Byrne, M. (2013). The impact of substance use disorder on families and children: From Theory to Practice. Social Work in Public Health, 28,(3-4), 194-205.

Lyons, K. (2006). Globalization and Social Work: International and Local Implications. British Journal of Social Work, 36, 365-380.

Meyers, R. J., Apodaca, T. R., Flicker, S. M., \& Slesnick, N. (2002). Evidence-Based Approaches for the Treatment of Substance Abusers by Involving Family 
Members. The Family Journal: Counseling and therapy for couples and families. 10(2), 281-288.

Miller, W. R., \& Rollnick, S. (2002). Motivational Interviewing (2nd edition). New York: The Guilford Press.

Mäntyranta, T., \& Kaila, M. (2008). Fokusryhmähaastattelu laadullisen tutkimuksen menetelmänä lääketieteessä. Duodecim 2008;124:1507-13. Suomalainen Lääkäriseura ja Kustannus Oy Duodecim. Retrieved from http://www.ebmguidelines.com/xmedia/duo/duo97349.pdf.

Nelson, A. (2012). Social Work with Substance Users. Washington DC: SAGE.

Nikulina, V., Widom, C. S., \& Brzustowicz, L. M. (2011). Archival report: Child abuse and neglect, MAOA, and mental health outcomes: A prospective examination: Mechanisms of compromised stress resilience during development and aging, Biological Psychiatry, 71, 350-357.

OECD/European Union (2014). Alcohol consumption among adults in Health at a Glance: Europe 2014, OECD Paris. Retrieved from http://dx.doi.org/10.1787/health_glance_eur-2014-20-en.

Orjasniemi T. (2005). Ottaako vai ei... Raittiuden ja alkoholin käytön sukupolvittaiset muutokset moraalivallin murtumisen ilmentyminä pohjoisella maaseudulla 1980-2000-Iuvulla. Acta Universitatis Lapponiensis 89. University of Lapland.

Orjasniemi, T., \& Soloviev A. (2014). Wet drinking cultures - Wet problems. Barents Studies Supplementary issue. Autumn 2014.

Ólafsdóttir, J. M., \& Hrafnsdóttir, H. (2011). Addiction and the family Halldór Sig. Guðmundsson (Ed.), In Research in Social Sciences: Pjóđarspegill.

Pinheiro, P. (2006). World report on violence against children: Secretary General's study on violence against children. Geneva: United Nations.

Sipola, M. (2014). Ratkaisu- ja voimavarakeskeinen voimapuu päihdeongelmaisten kuntoutusmenetelmänä In T. Orjasniemi (Ed.), Moniammatillisen päihdetyön käytäntöjä kehittämässä - kohdeilmiöitä, menetelmiä, strategioita ja rajapintoja. Available on http://www.urn.fi/URN:ISBN:978-952-484-741-4.

Sunday, S., Kline, M., Labruna, V., Pelcovitz, D., Salzinger, S., \& Kaplan, S. (2011). The role of adolescent physical abuse in adult intimate partner violence. Journal of Interpersonal Violence, 26, 3773-3789. 
Terveyden ja hyvinvoinnin laitos (2015). Päihdetilastollinen vuosikirja 2015 -

Statistisk årsbok om alkohol och narkotika, 2015 - Yearbook of alcohol and drug statistics, 2015 - Alkoholi ja huumeet. Suomen virallinen tilasto (SVT): SVT_PTVK_Sosiaaliturva_2015. THL. Retrieved from http://urn.fi/URN:ISBN:978-952-302-529-5.

The Code of Ethics for Social Work. British Association of Social Workers. January 2012

The University of the Arctic (2015). Thematic network on Social work. Retrieved from http://www.uarctic.org/organization/thematic-networks/social-work/.

Thompson, N. (2005). Understanding Social Work: Preparing for Practice. Second Edition. New York: Palgrave Macmillan.

University of Lapland (2013). The Study Guide 2013-2015. Master's Degree Programme (BCBU) in Comparative Social Work. Rovaniemi, University of Lapland.

Velleman, R., Templeton, L., Reuber, D., Klein, M., \& Moesgen, D. (2008). Domestic abuse experienced by young people living in families with alcohol problems: Results from a cross-European study. Child Abuse Review, 17, 387-409.

Vernig, M. P. (2011). Family roles in homes with alcohol-dependent parents: An evidence-based review. Substance Use \& Misuse, 46, 535-542.

Vincent-Lancrin, S. (2007). Cross-border Tertiary Education. A Way towards Capacity Development: OECD and The World Bank. Retrieved from http://siteresources.worldbank.org/EDUCATION/Resources/cross_border_ter tiary_education_Eng.pdf.

Walby, S., \& Allen J. (2004). Domestic violence, sexual assault and stalking: Findings from the British Crime Survey. Home Office Research Study 276. London: Home Office.

World Health Organization (WHO) (n.d.). Abuse (drug, alcohol, chemical, substance or psychoactive substance). http://www.who.int/substance_abuse/terminology/abuse/en/.

World Health Organization (WHO) (2014). Finland. Alcohol consumption: Levels and Patterns. Recorded alcohol per capita (15+) consumption (in litres of pure alcohol) by type of alcoholic beverage, 2010. Retrieved October the 18th, 2015. 
http://www.who.int/substance_abuse/publications/global_alcohol_report/profil es/fin.pdf.

World Health Organization (WHO) (2014). Iceland. Alcohol consumption: Levels and Patterns. Recorded alcohol per capita (15+) consumption (in litres of pure alcohol) by type of alcoholic beverage, 2010. Retrieved October the 18th, 2015.

http://www.who.int/substance_abuse/publications/global_alcohol_report/profil es/isl.pdf.

World Health Organization (WHO) (2014). Russian Federation. Alcohol consumption: Levels and Patterns. Recorded alcohol per capita (15+) consumption (in litres of pure alcohol) by type of alcoholic beverage, 2010. Retrieved October the 18th, 2015.

http://www.who.int/substance_abuse/publications/global_alcohol_report/profil es/rus.pdf.

World Health Organization (n.d.). Resources for the prevention and treatment of substance use disorders. Online (12 April 2016). Retrieved from http://www.who.int/gho/substance_abuse/en/index.html. 